\title{
An Analysis of Students in Independent Learning of Analytic Geometry During the COVID-19 Pandemic
}

\author{
Westi Bilda', Ahmad Fadillah ${ }^{2}$ \\ 1,2Mathematics Education, University of Muhammadiyah Tangerang, Indonesia \\ ${ }^{1}$ westibilda@umt.ac.id, 2ªhmadfadillah@umt.ac.id
}

\begin{tabular}{|c|c|}
\hline & ABSTRACT \\
\hline Article History: & \multirow{8}{*}{$\begin{array}{l}\text { The purpose of this study is to analyse the independence of students learning on } \\
\text { the flat analytic geometry of the Covid-19. This research was conducted on } \\
\text { students in the second semester with } 72 \text { resopondents consisting of } 15 \text { males and } \\
52 \text { females. Data retrieval is carried out using a self-sufficiency study poll as many } \\
\text { as } 20 \text { items of statements that have been compiled based on learning } \\
\text { independence indicators. The scale used in this study was the Likert scale. Data } \\
\text { analysis to know the independence of learning students used descriptive } \\
\text { analytical techniques with the ideal criteria namely the ideal mean and the ideal } \\
\text { deviation standard. Based on data analysis obtained by the results of } \\
\text { independence of learning with indicators: a self- confident is good enough } \\
\text { (31.75\%), the activeness is quite good ( } 37.50 \%) \text {, discipline is good ( } 52.10 \%) \text {, and } \\
\text { responsibility is good ( } 64.57 \%) \text {. }\end{array}$} \\
\hline Received : 04-07-2020 & \\
\hline $1: 1$ & \\
\hline $2: 12$ & \\
\hline Accepted : 14-09-2020 & \\
\hline : 03-10-2020 & \\
\hline Keyword: & \\
\hline lependent Learning; & \\
\hline
\end{tabular}

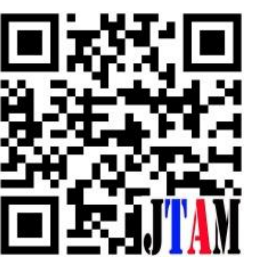

\begin{tabular}{cc} 
doi $\$$ Crossref & (c) () (O) \\
https://doi.org/10.31764/itam.v4i2.2575 & This is an open access article under the CC-BY-SA license \\
\hline
\end{tabular}

\section{A. INTRODUCTION}

Since the development of COVID-19 virus Pandemic (Corona Virus Disease-19) that struck the world in general and in Indonesia in particular, it changed all the lifestyles in all sectors of economics, health, education, and others. Education in Indonesia today will not want to be done in Daring or distance learning (called PJJ) as one solution and alternative by using various platform applications that exist such as Google meet, WhatsApp, zoom, teams, Google Classroom, YouTube, and so on. Yudhoyono (2020) policy of physical distancing to break the spread of the outbreak, forcing the change from formal education in the school to become learning from home, with the online system, on a national scale. In fact, the national exam this year was forced to be eliminated. Home scholling and online learning concepts are not a major choice of the implementation of the teaching and learning process throughout Indonesia, but in fact the online learning field is increasingly popular and implemented by lecturers, teachers, educational practitioners, and students today. Luthra \& Sandy (2020) mentions there are four 
ways that COVID-19 change the way we educate future generations. First, the worldwide education process is getting interconnected. Second, redefining educators' roles. Third, teaching the importance of life skills in the future. And, fourth, opening broader technological role in supporting education. In addition, Tam \& El-Azar(2020) expressed the corona-viral pandemic leading to three fundamental changes in global education. First, changing the way millions of people are educated. Second, a new solution for education that can bring much needed innovation. Third, the existence of digital disparity causes a new shift in education approach and can expand the gap.

Apart from the advantages and disadvantages of learning online, there are new problems such as learning material or lecture material that has not been delivered to the fullest, to stack the various tasks given. Puspitasari (2020) another problem with this online learning system is the access of information that is constrained by signals that cause slow access to information. Students sometimes fall behind with information resulting from insufficient signals. Consequently they were late in collecting a task given by the teacher. Not to mention for the teachers who examine many tasks that have been given to the students, making the gadget storage space increasingly limited. The application of online learning also makes educators think back about the models and learning methods to be used. The original teacher had already prepared the learning model to be used and then had to change the learning model.

From these problems and limitations, students should be able to optimize their independence in learning skills. The success of university learning is a goal that students will reach through individual abilities and motivations to self-monitor and control emotions, thoughts, and Actions (Ellis \& Helaire, 2018).

The process of teaching and learning activities in the lecture should involve the active role of students, where there will be a reciprocal process between lecturers and students. The roles and responsibilities of a lecturer designing and managing such students are able to construct their own knowledge. According to Damayanty \& Sumadi (2016) one of the most important factors that students must have is independence in learning, because with the independence of learning, students will conduct their learning activities with a sense of responsibility, strong willingness and a high disciplinary attitude that will affect the learning achievement increased. The student's success in mathematics learning is determined by the independence of each individual, the skills of the students achieved after learning experience is one of learning outcomes (Sudjana, 2017).

Nurhayati (2011)a student can be said to have an independence in learning when the student is able to study with his own initiative, with or the help of other relevant people to make important decisions in finding the need for learning. Widyasari (2017) In addition to his own initiative in the independence of learning also includes the ability of students to select and use the appropriate learning resources to be used to achieve the purpose of learning. The utilization of good learning resources is characterized by the selection of learning resources to suit the needs, availability of teaching materials, and interaction with the available teaching materials. With the use of learning resources such learning process will become more meaningful (meaning learning). Aini \& Taman (2012) Meaningful learning is a learning process that provides an understanding of information and experience through existing learning resources. Independence of learning is the nature and ability that the learners have 
to perform active learning activities driven by motives to control a competency and built with the provision of knowledge or competence that has been owned.

Furthermore, Suhendri (2015) stated that independence is learning is a learning activity that students do without relying on other people either friends or teachers in achieving the objective of learning that is to know the material or knowledge well with the students ' own awareness and can apply their knowledge to solve problems in everyday life. Basir (2012) independence learning is interpreted as a learning process that happens to one's self, and in its attempt to meet the person's learning is required to be active individually or not dependent on others, including not dependent on his teacher. Zimmerman in Pape et al, quoted by Tandililing (2013) there are three stages of learning independence, namely: thinking far forward, performance and control, and self-deflexion. This is in line with the opinions of Candy in Nagpal (2013) Independent learning is a process, method, philosophy of education in which students gain knowledge with their own efforts and develop their ability to solve problems critically.

Different from some of the opinions above, O'Rourke \& Carson (2011) inform that Learner autonomy is that learning has to start from the learner's existing knowledge. Schunk (2012) learning independence is the ability of students to exercise self-control and self-observation and to evaluate their cognitive processes personally. Independence will encourage students to achieve and be creative. Arista \& Kuswanto(2018) add that learning independence is defined as a form of awareness that arises from within themselves who want to receive information, manage it, and connect one part of information with another.

Based on the opinion of the experts above it is concluded that independence of learning is a person's ability in learning process activities to optimize and organize all teaching materials and learning resources precisely, effectively, and efficiently. But in reality, every student must have a different level of learning independence from one another, this may be due to family factors, the environment, and so forth, as discovered by Downey (2012) states that informal environments support a formal learning environment. It is in accordance with the opinion by Moos \& Ringdal (2012) that every student has individual differences in how to learn. The differences are seen in not only what students learn, but also how the students learn. Based on the background above, researchers are interested in conducting research on theanalysis of students in independent learning of analytic geometry during the COVID-19 pandemic. The purpose of this study is to analyse the independence of students learning on the flat analytic geometry of the COVID-19.

\section{B. METHODS}

This research was conducted to find out and describe the independence of students learning on the analytic geometry and performed in the second semester of the University of Muhammadiyah Tangerang. This research is a qualitative descriptive research. The samples in this study were selected by purposive sampling techniques and obtained as many as 72 respondents.

The data collection techniques in this study used questionnaires about the independence of learning. The questionnaire is a technique of collecting data done by giving a set of 
questions or written statements to the respondent to the answer (Sugiyono, 2016). The questionnaire (poll) in this study consisted of 20 statements based on learning independence indicators. In this study used an independence of learning indicator adaptation of Febriastuti et al (2013) as in Table 1 follows:

Table 1. Independent Learning indicators

\begin{tabular}{|c|c|c|}
\hline No & Indicator & ct assessed \\
\hline 1. & Confident & $\begin{array}{l}\text { a. I trust my own ability to work on the task compared to the ability of my } \\
\text { friends } \\
\text { b. I feel confident that I can work on questions without asking a friend for } \\
\text { help } \\
\text { c. I like trying new things in learning } \\
\text { d. I have a way to facilitate my learning }\end{array}$ \\
\hline & Active & $\begin{array}{l}\text { a. I learn of my own will } \\
\text { b. I ask the lecturer if I feel unclear about the subject matter } \\
\text { c. I learn though there are no exams } \\
\text { d. I read the material first before being taught by the lecturer } \\
\text { e. I feel challenged to learn more about the material presented by the } \\
\text { lecturer } \\
\text { f. I open up to the renewal of learning methods } \\
\text { g. I have the initiative to form a learning group with friends } \\
\text { h. I have a desire to try to practice difficult problems }\end{array}$ \\
\hline 3. & Discipline & $\begin{array}{l}\text { a. I collect the duties given by the lecturers in a timely manner } \\
\text { b. I take the time to learn } \\
\text { c. I immediately work on assignments when there is a job from the lecturer } \\
\text { d. Before learning, I prepared the necessary equipment }\end{array}$ \\
\hline & Resp & $\begin{array}{l}\text { a. I feel challenged to be able to solve the questions provided by the lecturer } \\
\text { b. I dare to answer the results of the assignment given by the lecturer } \\
\text { c. I have a desire to get good learning outcomes } \\
\text { d. If I get problem in understanding the material, I ask other people or } \\
\text { lecturers }\end{array}$ \\
\hline
\end{tabular}

The scale used in this study was the Likert scale, Sugiyono (2016a) of the Likert scale used to measure the attitudes, opinions and perceptions of a person or group of people about social phenomena. The choice of answers used in these instruments include very always (VA), often (OF), sometimes (SM), and never (NV). Data analysis to know the independence of students learning used descriptive analytical techniques with the ideal criteria namely the ideal mean and the ideal deviation standard and converted into a percentage form Table 2 and Table 3 below.

Table 2. Score and Category for Independent Learning

\begin{tabular}{|l|c|}
\hline \multicolumn{1}{|c|}{ Category } & Score \\
\hline always (SL) & 4 \\
\hline often (SR) & 3 \\
\hline sometimes (KD) & 2 \\
\hline never (TP) & 1 \\
\hline
\end{tabular}

Table 3. Criteria for measurement of study Independent Learning Indicators (questionnaire)

\begin{tabular}{|l|c|}
\hline \multicolumn{1}{|c|}{ Score } & Category \\
\hline Score $\geq$ Mean + SD & Good \\
\hline Mean - SD $\leq$ Score $<$ Mean + SD & Quite good \\
\hline Score $<$ Mean - SD & less good \\
\hline
\end{tabular}




\section{RESULT AND DISCUSSION}

The spread and filling of the poll was done using Google form due to the Covid-19 pandemic outbreak to 72 respondents consisting of 20 males and 52 females, with 20 items of statement organized by independent learning indicators and analyzed using the Likert scale. In general during the course of the process of learning to teach on the courses of analytical geometry students demonstrated confident, active, disciplinary, and good responsibility indicators.

Table 4. Survey results (questionnaires) Independent Learning

\begin{tabular}{cccccc}
\hline \multirow{2}{*}{$\begin{array}{c}\text { Independence of } \\
\text { Learning indicators }\end{array}$} & \multicolumn{5}{c}{ Category } \\
\cline { 2 - 5 } & Always & Often & Sometimes & Never & \\
\hline Confident & $31,75 \%$ & $51,37 \%$ & $14,15 \%$ & $2,73 \%$ & Quite good \\
\hline Active & $37,50 \%$ & $45,48 \%$ & $16,15 \%$ & $0,87 \%$ & Quite good \\
\hline Discipline & $52,10 \%$ & $40,62 \%$ & $6,93 \%$ & $0,35 \%$ & Good \\
\hline Responsibility & $64,57 \%$ & $30,92 \%$ & $4,16 \%$ & $0,35 \%$ & Good \\
\hline
\end{tabular}

Based on the Table 4 above, obtained the following information:

1. For an indicator of confidence with the items of the statements attached to the Table 1 obtained the results for the category: Always (VA) 31.75\%, often (OF) 51.37\%, sometimes (SM) $14.15 \%$, and never (NV) $2.73 \%$.

2. For an active indicator with the items of the statements attached to the table 1 obtained results for the category: Always (VA) 37.50\%, often (OF) 45.48\%, sometimes (SM) 16.15\%, and never (NV) $0.87 \%$.

3. For the disciplinary indicators with the items of the statements attached to the table 1 obtained results for the category: Always (VA) 52.10\%, often (OF) 40.62\%, sometimes (SM) $6.93 \%$, and never (NV) $0.35 \%$.

4. For the indicator of responsibility with the items of the statements attached to the table 1 obtained results for the category: Always (VA) 64.57\%, often (OF) 30.92\%, sometimes (SM) $4.16 \%$, and never (NV) $0.35 \%$.

Independence Learning students during the course learning process of analytical geometry during the COVID-19 pandemic can be seen from the AI, A2, and A3 respondents. Respondents A1 showed a good confident indicator it is seen that A1 always believes in self-esteem in the task of his friends ' abilities, always feel confident that they can work on questions without asking a friend's help, like trying new things in learning, and have their own way to facilitate learning. For the active indicator A1 shows that A1 learns on its own volition, learning despite no exams, reading the material first before being taught by the lecturer, feeling challenged to learn more about the material delivered by the lecturer, having the initiative to form a learning group with friends, has a desire to try to practice difficult questions. For the A1 disciplinary indicator indicates that the A1 may collect the duties given by the lecturer in a timely manner, taking the time to study, immediately working on the task when there is a task from the lecturer, and before learning always prepare the necessary equipment. For the responsibility indicator $\mathrm{A} 1$ to strengthen that the $\mathrm{A} 1$ feel challenged to be able to solve the 
questions given by the lecturer, dare to respond to the answer of the task given by the lecturer, have a desire to get the results of good learning, every problem in understanding the material always ask other people or lecturers.

Respondents A2 showed a good confident indicator that it seems that A2 has always believed in self-esteem in the task of his friends ' ability, always feel confident that they can work on questions without asking a friend's help, but less like trying new things in learning, and having their own way to facilitate learning. For an active indicator the A2 shows that A2 learns at his own volition, learns despite no exams, lacks material reading first before being taught by the lecturer, feeling less challenged to learn more about the material delivered by the lecturer, having the initiative to form a learning group with friends, has a desire to try to practice difficult questions. For an A2 discipline indicator shows that the A2 can gather the duties given by the lecturer in a timely manner, less able to take the time to study, immediately work on the task when there is a task from the lecturer, and before studying, I prepare the necessary equipment. For indicator of responsibility A2 to advise that A2 less feel challenged to be able to solve the questions given by lecturers, dare to answer the results of the task given by the lecturer, have a desire to get good learning outcomes, every problem in understanding the material always ask others or lecturers.

The A3 respondents showed a pretty good self-esteem indicator that the A3 has always believed in self-esteem in the task of his friends ' abilities, feeling less confident that they can work on questions without asking a friend's help, like trying new things in learning, and having their own way to facilitate learning. For an active indicator A3 shows that A3 learns at its own volition, learns despite no exams, lacks material reading first before being taught by the lecturer, feeling less challenged to learn more about the material delivered by the lecturer, lacking the initiative to form a learning group with friends, has a desire to try to practice difficult questions. For an A3 discipline indicator shows that the A3 skid gathers the tasks

given by the lecturer in a timely manner, less able to take the time to learn, immediately work on the task when there is a task from the lecturer, and before studying, do not always prepare the necessary equipment. For the A3 responsibility indicator to ensure that A3 is challenged to be able to solve the problems.

\section{CONCLUSION AND SUGGESTIONS}

Based on the results and research discussion above is concluded that from 72 respondents have independence of learning with indicators: self-confident is good enough, activeness is good enough, discipline is good, and responsibility is good. It is supported by research conducted by Faqihi et al (2015) that the success of learning should not only rely on face-to face, but it lies in the independence of learning. The advice related to this research is necessary to have ongoing research on education, especially mathematics education during the COVID-19 pandemic.

\section{ACKNOWLEDGEMENT}

A big thank you to all those who have assisted in this research, especially to the National Innovation Research Agency (BRIN) who have funded this research, and peer-to-Peer Mathematics Education Study Program of the University of Muhammadiyah Tangerang. 


\section{REFERENCES}

Aini, P. N., \& Taman, A. (2012). Pengaruh Kemandirian Belajar Dan Lingkungan Belajar Siswa Terhadap Prestasi Belajar Akuntansi Siswa Kelas Xi Ips Sma Negeri 1 Sewon Bantul Tahun Ajaran 2010/2011. Jurnal Pendidikan Akuntansi Indonesia. https://doi.org/10.21831/jpai.v10i1.921

Arista, F. S., \& Kuswanto, H. (2018). Virtual physics laboratory application based on the android smartphone to improve learning independence and conceptual understanding. International Journal of Instruction. https://doi.org/10.12973/iji.2018.1111a

Basir, L. O. (2012). Kemandirian Belajar atau Belajar Mandiri. Smadwiwarna.

Damayanty, D. Y., \& Sumadi, S. (2016). Hubungan Antara Kemampuan Numerik, Kecerdasan Emosi Dan Kemandirian Belajar Dengan Prestasi Belajar Fisika Siswa. 56 Jurnal Ilmiah Pendidikan Fisika-COMPTON, 3(2), 50-56.

Downey, A. (2012). Formal and informal learning environments. University of North Texas.

Ellis, J. M., \& Helaire, L. J. (2018). The Effects of Adolescent Self-Regulated Learning on Engagement in a College Access Program: An Exploratory Study. AERA Open. https://doi.org/10.1177/2332858418756051

Eti, N. (2011). Psikologi Pendidikan Inovatif. Pustaka Pelajar.

Faqihi, A., Retno, D., \& Saputro, S. (2015). Eksperimentasi Model Pembelajaran Problem Based Learning ( Pbl) Dan Kooperatif Tipe Group Investigation ( Gi ) Pada Materi Peluang Ditinjau. 3(10), 10481056.

Febriastuti, Y. D., Linuwih, S., \& Hartono. (2013). Peningkatan Kemandirian Belajar Siswa Smp Negeri 2 Geyer Melalui Pembelajaran Inkuiri Berbasis Proyek. UPEJ (Unnes Physics Education Journal), 2(1). https://doi.org/10.15294/upej.v2i1.1617

Luthra, P., \& Sandy, M. (2020). 4 Ways Covid-19 Education Future Generations. World Economic Forum. https://www.weforum.org/agenda/2020/03/4-ways-covid-19-education-future-generations/

Moos, D. C., \& Ringdal, A. (2012). Self-Regulated Learning in the Classroom: A Literature Review on the Teacher's Role. Education Research International. https://doi.org/10.1155/2012/423284

Nagpal, M. K. (2013). Independent learning and student development. Internasional, 2(2), 27-35.

O’Rourke, B., \& CARSON, L. (2011). Language learner autonomy: policy, curriculum, classroom: a festschrift in honour of David Little. Oxford ; New York: Peter Lang, 2010.

Puspitasari, R. (2020). Hikmah Pandemi Covid 19 Bagi Penddikan di Indonesia. IAIN SURAKARTA. https://iain-surakarta.ac.id/hikmah-pandemi-covid-19-bagi-pendidikan-di-indonesia/

Schunk, D. H. (2012). Learning Theories: An Educational Perspective (Subscription), 6th Edition. Pearson.

Sudjana, N. (2017). Penilaian Hasil Proses Belajar Mengajar. Rosdakaraaya.

Sugiyono. (2016a). Metode Penelitian Pendidikan (Pendekatan Kuantitatif, Penelitian Kualitatif, dan R\&D). In Alfabeta. Alfabeta.

Sugiyono. (2016). Metode Penelitian kuantitatif, kualitatif,dan R\&D, Alfabeta.

Suhendri, H. (2015). Pengaruh Metode Pembelajaran Problem Solving terhadap Hasil Belajar Matematika Ditinjau dari Kemandirian Belajar. Formatif: Jurnal Ilmiah Pendidikan MIPA. https://doi.org/10.30998/formatif.v3i2.117

Tam, G., \& El-Azar, D. (2020). 3 Ways the Coronavirus Pandemic Could Reshape Education. In World Economic Forum.

Tandililing, E. (2013). Peningkatan Komunikasi Matematis Serta Kemandirian BelajarSiswa SMA Melalui Strategi PQ4R Disertai Bacaan Refutation Text. Jurnal Pendidikan Matematika Dan IPA. https://doi.org/10.26418/jpmipa.v2i1.2174

Widyasari, W. (2017). Kemandirian Belajar Mahasiswa Pgsd Berdasarkan Ketersediaan Sumber Belajar. Jurnal Sosial Humaniora. https://doi.org/10.30997/jsh.v8i2.906

Yudhoyono, A. H. M. (2020). Pendidikan Indonesia di Tengah Pandemi Covid-19. Media Indonesia. https://mediaindonesia.com/read/detail/311137-pendidikan-indonesia-di-tengah-pandemicovid-19 